\section{Balking blood pressure "control" by older persons of Bambuí, Minas Gerais State, Brazil: an ethno- epidemiological inquiry}

\author{
A resistência contra o "controle" da pressão \\ arterial na população idosa de Bambuí, Minas \\ Gerais, Brasil: um inquérito etno-epidemiológico
}

\author{
Marilyn Nations 1 \\ Josélia O. A. Firmo 2 \\ Maria Fernanda Lima-Costa 2 \\ Elizabeth Uchôa 2
}

\section{Introduction}

This ethno-epidemiological inquiry aims to comprehend hypertension-related experiences in the elderly population of Bambui, in the State of Minas Gerais, Brazil. It combines ethnographic descriptions with statistical data. The subjective significance of factors associated with adequate arterial pressure control is explored. A baseline cohort of 26 people with hypertension, randomly selected from a total number of 1,494 residents over the age of 60, was interviewed utilizing signs, meanings and actions methodology. Multivariate analysis shows an association $(p<0.001)$ between female gender and monthly household income and treatment of hypertension and adequate blood pressure control. The number of doctor visits is associated with treatment but not with adequate blood pressure control. Conflicting cultural construction of "blood pressure problems" contributes to "non-adherence" to treatment. There is a fine line between blood pressure "control" and what is perceived as health professionals “controlling” patients' lives. Doctor-prescribed regimes are perceived as "prohibiting life's pleasures" and "controlling" personal liberty and free choice. Giving elderly people a voice regarding their social context can promote autonomy, wellbeing and happiness in later life.

Hypertension; Aging; Health of the Elderly; Cohort Studies
Hypertension is the most significant modifiable risk factor for older people. Treating arterial hypertension reduces cardiovascular morbidity and mortality and lowers all-cause mortality 1 . Although extensive variability exists in the proportion of hypertensive elderly who receive adequate treatment, depending on the setting, innumerous studies confirm they often go untreated 2,3. In treated patients, blood pressure control is inadequate, especially in developing countries 4,5. Adequate control is achieved in only $18 \%$ of older Mexican-American men and $30 \%$ of women 4 . Considering the growth in the number of elderly through 2025 - the majority of which will be concentrated in resource-poor countries - arterial hypertension is a public health priority, especially for minorities and elderly people living in poverty 5,6 . The population of people aged 60 or over in Brazil is rapidly increasing. By 2020, it will swell to an estimated 32 million - the fifth largest elderly population in the world 6 . Stroke and coronary heart disease are leading killers of older adults, making community-based control of hypertension a must for the Brazilian Health Ministry (Ministério da Saúde) 7.

This ethno-epidemiological study investigates correlates of adequate/inadequate arterial pressure treatment and control among the lowincome, low-literacy elderly population. We creatively combine multivariate regression analysis 
applied to epidemiology with ethnography to provide descriptions of daily life. Apart from identifying vulnerable populations and risky behavior, "hybrid" findings help to understand the complex human beliefs and behavior that underlie associations. We argue that giving elderly citizens a voice 8 promotes patient-centered 9 cardiovascular care and healthy living in later life.

\section{Bambuí: a small tropical town} in transition

This ethno-epidemiological study was conducted in Bambuí (population 15,000), in the Minas Gerais State, Brazil. Life expectancy at birth is 70.2 years and most deaths among the elderly are caused by cerebrovascular disease, coronary heart disease and Chagas disease. Although the transmission of Chagas disease - through Trypanosoma cruzi infection associated with poor housing conditions - was controlled 20 years ago, seropositivity is still high as a consequence of cohort effects. Bambuí boasts a 62-bed general hospital and health center and the physician/inhabitant ratio is $1: 1,000$. Approximately $43 \%$ of adults over the age of 25 have completed less than 4 years of schooling. The Human Development Index (HDI) is 0,70 10 .

Life in Bambuí is changing. Lifestyles firmly rooted in farming, cattle-raising and dairy-production are increasingly subject to the forces of globalization which are invading inland rural areas in Brazil. Religious faith and solidarity and strong social bonds across generations and between families are values cherished by the town's mainly catholic (95\%) population. A volunteer spirit is at the heart of community life. Leisure time is spent at family gatherings, church bazaars and school plays and communal preparation of food and eating are part of everyday life. The region's culinary tradition, "cozinha mineira", is notorious for its high calorie and hypercholesterolaemic "fatty food" ("comida gorda"), rich in saturated and polisaturated fats such as 11: full cream milk, yogurt, condensed milk, cheese bread, sugared fruits, beans with pork ("feijão tropeiro", "tutu de feijão"), deep-fried pork scratchings (“torresmo") and pork-butter cookies.

\section{Methods}

This ethno-epidemiological inquiry is part of the Bambuí Cohort Study of Aging: a populationbased cohort study of aging. The baseline cohort was established in 1997. All 1,742 residents over the age of 60 were invited to participate. Standard procedures were used to measure arterial blood pressure (the mean of the second and third measurements) of 1,494 people (86\%). All those identified as having hypertension in the baseline cohort were selected for the study. The criteria used to define hypertension were systolic pressure of $\geq 140 \mathrm{mmHg}$, and/or diastolic pressure of $\geq 90 \mathrm{mmHg}$, and/ or current use of hypertension medication (containing at least betablockers, diuretics, calcium channel blockers, angiotensin converting enzyme(ACE) inhibitors, ACE antagonists, central alpha-blockers and/or vasodilators) 12 .

Exploratory variables (except age) were selected based on previous ethnographic insights, including: gender, conjugal status, number of completed years of schooling, monthly household income measured in number of minimum wages (US\$ 120.00 in 1997) and number of visits to the doctor in the previous 12 months. Data was obtained by interviewing, utilizing a structured, pre-coded questionnaire 10 . Two separate analyses compared the characteristics of treated with non-treated informants - among those who were aware of being hypertensive (previous doctor diagnosis) (Table 1) and hypertensive elderly with adequate blood pressure control (systolic blood pressure of $<140 \mathrm{mmHg}$ and/or diastolic blood pressure of $<90 \mathrm{mmHg}$ ) - with those having higher arterial pressure (Table 2). For the multivariate analysis, prevalence ratios and $95 \%$ robust confidence intervals were calculated using Poisson regression with Stata version 11.0 (Stata Corp., College Station, USA).

Of the 919 cohort members identified as having hypertension, 30 were randomly selected for the ethnographic study. Interviews were conducted between September and October 2002 at the patient's residence by native Portuguese speakers. In-depth interviews were carried out with 26 of the 30 informants (19 women and seven men). The remaining four informants - all employed men - were unavailable during weekdays for interviewing. Anthropologists (who had been conducting fieldwork in Bambuí since 199712 and were, therefore, familiar with the residents) were invited to the homes of selected informants. As is the custom, informants offered researchers homemade cookies, cake, cheese and "cafezinho". After engaging in friendly "small talk”, researchers explored the informant's perceptions of hypertension. A semi-structured interview guide was employed to explore lay rationalities, health behavior and choice of therapy. The signs, meanings and actions methodology (Corin et al.) 13 was utilized to collect, systematize and analyze interview data. Actual illness episodes were reconstructed in order to probe the informant's knowledge of diagnosis, signs, etiology, severity 
Association between treatment of hypertension among informants aware of being hypertensive. The Bambui Cohort Study of Aging.

\begin{tabular}{|c|c|c|c|c|}
\hline \multirow[t]{2}{*}{ Characteristics } & \multicolumn{2}{|c|}{ Hypertension treatment } & \multirow{2}{*}{$\begin{array}{c}\text { Adjusted PR * } \\
(95 \% \mathrm{Cl})\end{array}$} & \multirow[t]{2}{*}{$\mathrm{p}$-value ** } \\
\hline & Yes $(n=578)$ & No $(n=273)$ & & \\
\hline \multicolumn{5}{|l|}{ Age group (years) } \\
\hline $60-69$ & 59.9 & 58.6 & 1.00 & \\
\hline $70-79$ & 32.2 & 31.9 & $1.00(0.91-1.10)$ & 0.947 \\
\hline$\geq 80$ & 8.0 & 9.5 & $0.91(0.76-1.03)$ & 0.263 \\
\hline \multicolumn{5}{|l|}{ Gender } \\
\hline Male & 24.4 & 49.5 & 1.00 & \\
\hline Female & 75.6 & 50.6 & $1.46(1.28-1.66)$ & $<0.001$ \\
\hline \multicolumn{5}{|l|}{ Married } \\
\hline No & 45.5 & 52.0 & 1.00 & \\
\hline Yes & 54.5 & 48.0 & $1.02(0.92-1.12)$ & 0.734 \\
\hline \multicolumn{5}{|c|}{ Number of years of schooling } \\
\hline$<3$ & 65.7 & 70.0 & 1.00 & \\
\hline $4-7$ & 27.2 & 23.8 & $1.07(0.96-1.1 .19)$ & 0.220 \\
\hline$\geq 8$ & 7.1 & 6.2 & $0.99(0.82-1.20)$ & 0.921 \\
\hline \multirow{2}{*}{\multicolumn{5}{|c|}{$\begin{array}{l}\text { Monthly family income measured in } \\
\text { number of Brazilian minimum wages }\end{array}$}} \\
\hline & & & & \\
\hline$<2$ & 28.5 & 34.9 & 1.00 & \\
\hline $2-3.9$ & 37.7 & 39.4 & $1.05(0.94-1.18)$ & 0.392 \\
\hline$\geq 4$ & 33.9 & 25.7 & $1.18(1.05-1.33)$ & 0.006 \\
\hline \multicolumn{5}{|c|}{ Number of visits to the doctor in previous } \\
\hline \multicolumn{5}{|l|}{12 months } \\
\hline None & 8.0 & 17.6 & 1.00 & \\
\hline One & 25.3 & 18.5 & $1.19(0.94-1.50)$ & 0.144 \\
\hline Two & 15.0 & 18.0 & $1.39(1.11-1.75)$ & 0.004 \\
\hline Three or more & 55.5 & 42.1 & $1.42(1.15-1.75)$ & 0.001 \\
\hline
\end{tabular}

PR (95\% Cl): prevalence ratio and 95\% robust confidence interval estimated using Poisson regression.

* Adjusted for all remaining variables listed in the table;

** p-value: Wald's test.

and experiences of barriers to access, treatment, management strategies and outcomes. Interviews were recorded and transcribed verbatim. Transcriptions were analyzed and emerging themes were coded.

The Bambuí Cohort Study and this anthropological study were approved by the Research Ethics Committee of the René Rachou Research Center of the Oswaldo Cruz Foundation (Centro de Pesquisas René Rachou, Fundação Oswaldo Cruz). Informants' names are fictitious.

\section{Results}

\section{Epidemiological evidence}

Of the total of 1,494 elderly people who had their arterial blood pressure measured, 919 (61.5\%) were found to be hypertensive. Of these people, 851 (57\%) were aware of being hypertensive. Among the hypertensive participants, 635 (69.1\%) were undergoing treatment and 473 (51.5\%) used adequate measures to control their blood pressure (systolic blood pressure of $<140 \mathrm{mmHg}$ and diastolic blood pressure of $<90 \mathrm{mmHg}$ ). Table 1 shows the characteristics of hypertensive participants according to the type of treatment used. The results of the multivariate analysis revealed that female gender, higher family incomes and 
Association between adequate blood pressure control among informants treated with antihypertensive medication.

The Bambui Cohort Study of Aging.

\begin{tabular}{|c|c|c|c|c|}
\hline \multirow[t]{2}{*}{ Characteristics } & \multicolumn{2}{|c|}{ Adequate blood pressure control * } & \multirow{2}{*}{$\begin{array}{l}\text { Adjusted ** PR } \\
\quad(95 \% \mathrm{Cl})\end{array}$} & \multirow[t]{2}{*}{$\mathrm{p}$-value } \\
\hline & Yes $(n=248)$ & No $(n=387)$ & & \\
\hline \multicolumn{5}{|l|}{ Age group (years) } \\
\hline $60-69$ & 61.2 & 55.6 & 1.00 & \\
\hline $70-79$ & 29.8 & 33.9 & $0.90(0.72-1.12)$ & 0.350 \\
\hline$\geq 80$ & 8.1 & 10.6 & $0.77(0.53-1.12)$ & 0.174 \\
\hline \multicolumn{5}{|l|}{ Gender } \\
\hline Male & 19.4 & 29.2 & 1.00 & \\
\hline Female & 80.7 & 70.8 & $1.47(1.12-1.93)$ & 0.006 \\
\hline \multicolumn{5}{|l|}{ Married } \\
\hline No & 55.2 & 54.0 & 1.00 & \\
\hline Yes & 44.8 & 46.0 & $1.01(0.81-1.24)$ & 0.961 \\
\hline \multicolumn{5}{|c|}{ Number of years of schooling } \\
\hline$<3$ & 59.5 & 68.2 & 1.00 & \\
\hline $4-7$ & 31.6 & 25.1 & $1.28(1.03-1.60)$ & 0.028 \\
\hline$\geq 8$ & 8.9 & 6.7 & $1.34(0.94-1.92)$ & 0.109 \\
\hline \multicolumn{5}{|c|}{$\begin{array}{l}\text { Monthly family income measured in } \\
\text { number of Brazilian minimum wages }\end{array}$} \\
\hline$<2$ & 26.9 & 28.9 & 1.00 & \\
\hline $2-3.9$ & 37.1 & 37.5 & $1.01(0.79-1.29)$ & 0.949 \\
\hline$\geq 4$ & 35.9 & 33.8 & $1.12(0.71-1.77)$ & 0.909 \\
\hline \multicolumn{5}{|c|}{ Number of visits to the doctor in previous } \\
\hline \multicolumn{5}{|l|}{12 months } \\
\hline None & 6.9 & 9.3 & 1.00 & \\
\hline One & 17.7 & 19.1 & $1.12(0.71-1.77)$ & 0.623 \\
\hline Two & 18.2 & 17.8 & $1.20(0.76-1.90)$ & 0.429 \\
\hline Three or more & 57.3 & 53.8 & $1.23(0.81-1.87)$ & 0.330 \\
\hline
\end{tabular}

PR (95\% Cl): prevalence ratio and 95\% robust confidence interval estimated using Poisson regression.

* Systolic blood pressure $<140 \mathrm{mmHg}$ and diastolic blood pressure $<90 \mathrm{mmHg}$;

** Adjusted for all remaining variables listed in the table.

number visits to the doctor in the previous 12 months were factors positively and significantly associated with being treated. As shown in Table 2 , female gender and having an intermediate level of education (4 to 7 years of completed schooling) were the only factors significantly associated with using adequate measures to control blood pressure.

\section{Ethnographic evidence}

All 26 informants had heard of hypertension, calling it "high pressure" or "pressure problems". Arterial hypertension is perceived as an illness that "attacks from inside", that "alters" the person, leading to a generalized "bad feeling" ("ruindade") and "feeling unwell" ("mal estar") all over, with "uncontrollable trembling and shaking” ("ficando bambo", "bambeza"), dizziness and feeling detached from oneself: "I'm not my normal self (...) my mood and temper completely change (...) even my libido!". After feeling excessively emotionally sensitive - irritable, happy, sad, shocked, surprised - my blood "boils" and pressure rises: “Anxiety (...) emotion (...) watching bad news on television, raises my blood pressure!".

Two emotions - "coutrariness" ("contrariedades") and "irritation" ("amolações") - are perceived as particularly harmful. Experiencing conflicts (bickering, nagging, arguments, etc.) or "the bitterness of life" (injustice, feeling unsatisfied, death, problem drinking) causes growing tension, irritability and rising blood pressure. A 
retired woman says: "If I feel stressed or upset by something - a problem at home feeling unsatisfied with something - you can measure my blood pressure rising!". Marriage and birth are situations which lead to a natural increase in "contrariness" and "irritation". Dona Geralda, 67, mother of three adult children, takes medication to control her blood pressure of 125/79: "When single, my pressure was very, very low (...) after marriage, there was so much 'contrariness' and pressure!". Dona Rita, 83 and a great grandmother, explains: “In a big family like mine, there's always some reason to get upset (...) If it's not your kids, it's your grandkids! I worry myself to death about them!". A widow, 66, (taking pills to control blood pressure of 145/75) agonizes over her grandson, who "steals my happiness" and makes her blood pressure rise: "My family is not very close. My son is divorced and my grandson never visits me (...) What happiness can life hold without your own flesh and blood? This makes me suffer (...) it sends my blood pressure sky high!". "Contrariness" and "irritation" are also caused by global conflicts, political corruption and social inequality, explains a 70-year-old, retired farmer with 4 years of completed schooling: "Modern day life is agitated (...) too many worries! Is there anyone who isn't worried about war in the Middle East? (...) about their kids on the streets? (...) all the car accidents? (...) corruption in Brazil? Well, all these things worry me to death (...) mess-up my blood pressure!. My body turns into a pressure cooker waiting to explode!".

According to popular pathophysiology, the first sign of "high blood pressure" is a feeling of "nervousness and irritability". Feeling emotionally sensitive can test your patience, make you feel "agitated and distressed" and "irritated" and make sleeping impossible. During "fits of anguish" ("angústia de choro"), mounting pressure and "bad feelings" are released. Emotional stress is somatized in "the guts", causing nausea, indigestion and vomiting. "Clutching pains" radiate upward causing "chest pains" and "palpitations" inside the heart ("batedeira no coração"). Severe "tightening" restricts the heart from beating and pumping blood and oxygen to the body's extremities. Arms and legs "shake wildly" ("ficar bamba"). Fingernails and lips turn purple. Blood collects and stagnates in the body's main cavity. "Trapped blood" surges upward and "suspends", leaving telltale signs: red blotches on the neck, "hot flushes" ("calorão") and sharp cervical pains. As blood pressure quickly rises, facial "flushing" occurs, the ears "throb", the forehead "tightens", the tongue rolls and speech begins to slur. Trapped inside the skull, "suspended blood" causes "head pressure", pounding headaches and dizziness ("tontura", "zonza", "zonzeira"); the head turns "heavy" and "bad". The victim experiences difficulty concentrating and thinking and feels "lightheaded" ("fico boba"). The brain bursts like a balloon ("estoura") due to intracranial pressure, causing massive hemorrhaging ("blood spilling"), heart attack and sudden death. However, blood pressure may fall or "zero out." The body "cools down”, becoming "clammy and cold like a cadaver!". "Falling blood" is felt in the ears, gums, back and lungs, with sensations of "disappearing", "numbness" and "faintness". If blood pressure "rises and falls" uncontrollably, "living is torture" and even performing the most simple tasks, such as eating, walking and washing, is difficult.

Stabilizing wild "up-and-down" fluxes in blood pressure demands keeping a "good head." High emotion situations (e.g. visiting cemeteries, "heated" arguments) must be avoided at all costs, and letting off (emotional) steam by "blankingout worries", talking to friends and "contemplating nature" is important. "Head pressure" is also relieved by reversing blood flow to the brain by lying down, holding the head up straight and wearing flat-heeled shoes. To alleviate the symptoms, the elderly drink medicinal teas ("chuchu", "cidreira", passion fruit, garlic, lemon, eggplant) and restrict the intake of salt, sugar, pork, alcohol and cigarettes.

\section{Male gender}

Ethnographic evidence supports epidemiological findings that older men are more likely to experience inadequate treatment and ineffective control of blood pressure than women. Field researchers observed that attitudes and actions tended to differ between men and women. Four of the proactive informants (with blood pressure of 143/98 and 140/85) were men that strongly denied or downplayed symptoms, were pragmatic about test results, lacked patience to spend long hours queuing and were decisive in abandoning treatment. A 70-year-old retired farmhand downplays the severity of his high blood pressure: " $I$ know my pressure is bad but the last time I went to the doctor was two years ago! I say, just leave it for tomorrow (...) Tomorrow I'll go (...) it's [high blood pressure] like a little bird (...) it flies away!" A poor, illiterate man, 77, with pressure of 162/68 affirms: "If I'm broke, I don't bother to seek help. That's how it is! Standing in line (...) in the middle of all those people bothers me (...) I can't stand waiting!". Another man stops treatment without any apologies, pleasantries or justifications: "The doctor said, once I start talking pressure pills, I'm hooked for life (...) I can never stop! So why even 
start?". An 83-year-old ex-construction worker with hypertension (164/91) takes matters into his own hands: "My doctor prescribed two pills per day (...) but I'm only taking one pill once a day. I decided to stop (...) it was my decision!".

\section{Low household income}

Ethnographic evidence explains the negative epidemiological association between treatment of hypertension and household income. Poor informants mention the following difficulties encountered in accessing treatment: disability, immobilizing depression, no one to accompany them to the clinic, having to spend long hours queuing starting at dawn, lack of availability of appointments, doctor no-shows, health service staff strikes and irregular supply of pills. The patient's socioeconomic status - not the severity of the illness - determines access to quality care, laments a retired businessman, 70 , with blood pressure of 187/100: "Doctors prescribe according to patients' financial situation (...) one kind of medicine for the guy who's got money (...) another kind if he's broke!". Some are forced to purchase pills or interrupt therapy: "There are so many needy people! They can't give free pills to everyone. So, I have to buy them (...) I can't go without my pills!". The invisible costs of using the Unified National Health System (SUS) in Brazil pushes the needy towards private health care, criticizes a housewife, 72, that takes Higroton (Novartis, São Paulo, Brazil) to control her blood pressure of 92/81: “It is difficult (...) you have to go at night (...) give your name (...) then return early the next day (...) take your queue ticket (...) so many people!". With little money, Zelma, 69, charges her pills on her credit card: "No money? I use my credit card to buy pills (...) until our pension arrives”. Another buys medicine instead of buying food: "I make sacrifices (...) skip the hassle of eating (...) but I have to buy the pills!". Although 12 informants reported "no difficulties" in making an appointment to see the doctor, three had private health insurance, pay private doctors, live near a clinic or have a "friend on the inside" who makes their appointments.

\section{Patient non-adherence to treatment}

Ethnographic evidence confirms the complex epidemiological association between frequent health service use and increased treatment of hypertension. It denies, however, a link between frequent health service use and increase in the effective control of blood pressure. As the number of patient visits to hospital or the clinic increases, attentive nurses and physicians are more able to screen, detect and prescribe medication. The majority of patients with hypertension were diagnosed during a routine visit to the doctor or when asking for a doctor's sick note, a legal requirement in Brazil to justify sick leave. One informant was diagnosed by the Bambuí Cohort Study of Aging staff. During repeated, routine blood pressure screenings, apparently healthy elderly people with high blood pressure are identified and referred immediately for examination and treatment. Only four informants were discovered to be hypertensive upon falling sick, seeking a doctor and measuring their blood pressure. Repeated contact with healthcare providers who prescribe medication does not necessarily result in effective blood pressure control. The issue is elderly patients' non-adherence to prescribed medication and lifestyle changes. Medication "non-compliance" - modifications, deviations and alterations to the prescribed indications - is a problem. Of 26 informants, six never took the prescribed medication; 20 took pills but 10 modified recommended doses or temporarily interrupted pill taking. Of the 10 currently taking correct dosages, 6 interrupted treatment in the past. Only 4 take the regular recommended dosages. The elderly alter prescriptions according to their own rational judgment: "The doctor told me to take a pill every single day but yesterday I skipped a day. It was too late to take it!". A poor patient substitutes costly blood pressure medication for a cheap home remedy: "My money ran out (...) so I suck a salty olive. It's my salvation!". Another decided "to simply stop everything!".

Because patients "regulate" or "balance" blood pressure at a level which is subjectively perceived by them as "normal", the physical sensation of pressure - not a fixed measure - is what counts: "When my blood pressure is 16 or 15, I feel that it's normal (...) it's never less than this!". To stabilize pressure, the elderly use multiple, proactive strategies: halving pills, double-dosing, skipping taking pills, etc. A 67-year-old housewife reveals: "I halve the pills by myself, because a whole pill lowers pressure. I just break the pill into little pieces (...) to see if it rises again!". Before suffering a stroke, Dona Maria das Graças, 73, with blood pressure of 187/87, "regulated" her high pressure: "I took my pills (...) then rested a bit (...) stopped for a bit (...) until my pressure was regulated!". A 86-year-old seamstress, with blood pressure of 133/61 and three completed years of schooling, stopped taking pills, fearing the effects of blood-pressure-lowering: "I measured my pressure (...) it was 2. But I don't know if the minimum was 5, 6 or 7 (...) I'm scared to death that the bottom number reading lowers too much!". It is believed that rising blood pressure is 
an "inevitable" part of growing old and pressure pills are "too strong" for aging bodies. If death is near, treatment is seen as "senseless". A 73-yearold man jokes: "High pressure is just age catching-up (...) it's one of the bad things of growing old ['mal da velhice'] (...) I'll never have a young person's blood pressure!". The elderly complain that free government-distributed and low-cost generic drugs are "fake", "weak" or "not worth taking”. A perplexed 82-year-old says: "One doctor prescribed small pills (...) another doctor prescribed some big pills (...) saying these small ones are not worth taking! (...) What a joke!". When aging bodies become "used to", "nauseated" or "abused" by pills, the elderly desist from therapy rather than increasing the dosage: "The doctor tells us to take the pills. We do exactly what he says. But you have to keep increasing the dose for them to work. They stop working!". Others abandon drugs due to their side-effects: "The doctor prescribed pills that really messed me up! I don't know if they were too strong or what (...) I became very ill. My friends say that Capoten [Laboratório Bristol-Myers Squibb, São Paulo, Brazil] really does you in! [“capota mesmo”!]”. Several warn of growing physically "addicted" to pills: "I'd like to stop taking these pills (...) to be independent (...) but I've become addicted!". "Non-compliance" is a positive step toward kicking the "bad pill habit” and freeing oneself from future chemical dependency.

Bambuí's elderly resist complying with doctors' instructions against eating "fatty foods" and lifelong bad food habits - which give immense pleasure in later life. Strict diets eliminate "everything that's good in life!". Seventy seven year-old Dona Maria complains: "My doctor told me to eliminate fat, meat, and cream. I complained to him: 'Oh my God, I'm not allowed to eat anything that's delicious!' (...) Doctor, come and visit my hometown and drink some delicious creamy milk (...) eat hot cheese buns soaked in cream (...) it's so delicious!. He replied: "Dona Maria, you are not allowed to eat any of your favorite foods!". A 71-year-old, single woman, living alone complains: "The doctor even told me not to drink herbal tea made by my godmother! I can't drink anything (...) anything, anything at all-only the medicines he prescribes!". For Dona Fatima, a 75-year-old woman living alone, her doctor's strict orders not to watch emotionallycharged soccer games on television is devastating: "I love soccer; I should have been born a man! Once, after watching the Brazilian Championship on television, I mentioned to my doctor that my heart couldn't stand watching anymore (...) It was too exciting! So he strictly prohibited me from watching! Now I'm really in a fix (...) I can't do anything anymore!". In Brazil - where soccer is a national passion - such restrictions isolate the elderly from lively social gatherings, contributing to depression.

Informants criticize that clinical communication takes away the elderly person's voice and ignores their life experiences. Doctors' instructions are perceived as authoritarian orders - not professional advice guiding patients' decisions. Displays of "disinterest", "cold silence", and "telling off" undermine patient's confidence in caregivers: "I told my doctor about how I soaked my burning ears at night to cool-down the 'burning sensation' (...) He just sat there in silence (...) didn't say a word!'. A 66-year-old housewife adds: "First thing the doctor does is tell me off! He's very frank." Older patients are intimidated by authoritarian doctors' "orders" or "rules": "To control pressure, the guy must get back on the rails. It's like a train running off the rails (...) getting him back in line! If he's in the right gear, he goes forward. If not, he stops dead in his tracks!". Other patients criticize professionals' technical ability. An 82year-old-man watching the nurse take his blood pressure criticizes her accuracy: "The girl at the health center doesn't know how to measure my blood pressure. She said my pressure was 120/80. I knew it was higher because of the tightening in my heart. The doc double-checked. It was 190/71!". Others secretly resist doctors' orders in protest: "My head was exploding so the nurse gave me a pill and cup of water. I took one sip (...) when she left I spat the rest out!".

Elderly patients go against doctors' orders in the pursuit of personal liberty. Assertive, older informants "stop taking medication on my own", feel that my pressure is low "based on my thinking" and "decide to interrupt taking blood pressure pills on my own!". Part of a hardy breed of rural laborers that brought up a large family on a minimum wage and with little formal education, an active 83-year-old farmer's wife ignored her doctor's "absurd orders": "It's difficult to walk up and down these hills (...) but at home I do all my chores by myself, everything that God wills!'. Dona Hilma, a 78-year-old farmer spent her entire life working hard on the land and gave birth to 7 children- several on the farm - without consulting a doctor: "I had 7 children, all normal births (...) alone at home (...) a few in the fields (...) they're all grown-up, married (...) just fine!". Strongwilled, Dona Hilma values her liberty. She, like other widows, has outlived her husband and 2 children. She fights on alone to keep the "spark of life glowing"; monitoring blood pressure is a fleeting concern. 


\section{Discussion}

This ethno-epidemiological study combines statistical and ethnographic evidence to identify, clarify, support and enhance statistical associations. Apart from numerical correlates, the study provides a vivid subjective portrait of the elderly person's perceptions of high blood pressure. The elderly live with "blood pressure problems" according to popular keys to interpretation that open the doors to the patient's subjective experience of illness 14,15 and the social dimensions of "sickness" 16. Since the mid-1980s, anthropologists and psychiatrists 17,18,19,20 in Brazil have been exploring the cultural construction of human affliction in local worlds. Duarte's 17 study of the lived experience of "nervios" (nerves) among the urban working class is a classic example. The informants culturally construct notions of "pressure problems" - including doctors' recommendations. Based on this layman's view, they take determined steps to resolve "pressure problems" within their local, moral world 15. Eliciting patients' emic or subjective interpretation of hypertension is indispensible for improving clinical communication and care 21 .

Ethno-epidemiological studies offer a promising new methodological approach to enhance the meaning of statistical associations 22. Dialogue between medical and social sciences is stimulated during such interdisciplinary engagement. In this study, we witness how combining methods provide a holistic portrait of hypertension. However, combining quantitative and qualitative approaches is challenging. It requires negotiating divergent epistemological principals and rationale 21 . Without a compass to navigate uncharted conceptual waters, we forged our own methodological pathway. First, we critically reviewed background anthropological evidence on this setting 12,23. Initial descriptive findings stimulated a search for new epidemiological correlates of adequate pressure control. Emerging epidemiological associations prompted a reanalysis of ethnographic data, focusing on the cultural significance of statistical associations. Such qualitative-quantitative synergism yielded "living evidence" 22 about the patient's experience of hypertension. Ethnography's detailed descriptions of everyday life are linked to epidemiological associations and vice versa. Continued dialogue between anthropologists and epidemiologists is crucial to refine the ethno-epidemiological approach.

Evidence corroborates earlier findings that associate female gender with treatment and control of high blood pressure $4,23,24$, an association observed after adjusting for potential confounders, such as the use of health services. Although the male gender is underrepresented in this study - due to daytime employment obligations - participating elderly men showed a tendency to negate illness, downplay symptoms, resist help, forgo appointments, terminate care and carry out self-treatment. Such behavior echo "machismo" 25, or male dominance, previously observed in Bambuí 26. Although these results are suggestive, generalized gender based differences cannot be concluded from this small sample of men. Narratives suggest that culturally valued "machismo" 25 , instead of helping, may hinder control of hypertension and health in men in later life. Rebhun 20, (p. 168), argues that gender roles in Northeast Brazil contain both implicit and explicit emotional expectations: "Both sexes are imprisoned within the expectations of their emotionally informed social roles". How Brazilian men express/deny heart-felt sentiment and roles in any genderspecific construction of hypertension needs to be explored.

The association between household income and treatment of hypertension is not surprising in Brazil, a country rife with social inequality. The 1998 Brazilian National Household Sample Survey confirms: elderly with the lowest household incomes present the worst health profiles and most restricted access to/use of health services, despite free, universal healthcare 27. Although socioeconomic stratification is less pronounced in Bambuí, even small income differences are sufficient to explain, in part, health inequalities 28. Ethnographic studies in Araraquara (São Paulo, Brazil) 29 and Bambuí 30 confirm that lack of money hinders access to medical treatment, medication and blood pressure control. Money is an advantage for paying for a private doctor, health plan, prescribed medicines or a personal "stand-in" to wait in line or make an appointment. Having financial resources appears essential for maintaining cardiovascular treatment/ control and well-being in later life. Our data corroborates that lack of financial resources restricts access to treatment. However, even those without easy access to drugs seek treatment motivated by culturally-shaped rational thinking. They overcome economic obstacles, employing a variety of strategies to treat "pressure problems" such as: charging pills to credit cards, forgoing meals and depending on personal favors and alternative treatments. Such resilience in the face of scarcity suggests a far greater degree of complexity between the economic context and treatment of hypertension than statistical associations reveal, providing a stimulating pathway for further interpretation. 
Surprisingly, no association was found between multi-generational living and adequate blood pressure control in this community-dwelling elderly population. It was expected that living together with a safety net of adult children and grandchildren would significantly enhance the informant's adherence to treatment. However, ethnographic data suggests the existence of confounding factors. The two principal ethnoetiologies of "pressure problems" - "contrariness" and "irritation" - suggest that "family problems" are the principal cause of rises in blood pressure. Family conflicts, disagreements, disputes, arguments, daily tension, "contrariness", (literally, "worrying oneself sick") have been identified 31,32 as probable causes of hypertension. The main issue is, therefore, not necessarily household structure or the number of generations cohabiting, but the emotional quality of interpersonal relations with older members. The effect of emotional trauma on cardiac pathophysiology has been convincingly demonstrated with the discovery of Tako-tsubo cardiomyopathy 33 , or "broken-heart syndrome". We argue that the informants' "situated discourse" 34 on "contrariness" and "irritation" is a cultural characteristic through which experiences of illness and emotions are articulated, organized and expressed. Future studies should compare the emotional aspects of hypertension and related folk-defined illnesses and probe the prevalence of popular explanations as rationales for varying blood pressure treatments.

Explaining why $75 \%$ of the elderly in this study failed to adequately control blood pressure, despite visiting health providers, is more complex. A clash between the doctors' construction of the disease and the patients' subjective experiences of hypertension as regards "high blood" 31 and "hyper-tension" 32 , is likely to undermine adherence. The voices of Dona Maria, Dona Fatima and others and their poignant complaints, criticisms and outrage at therapeutic lifestyle measures ordered by doctors, beg our attention. "Controlling" blood pressure goes beyond monitoring diastolic and systolic pressure levels. It means "controlling" the lives of the elderly! Adherence to therapeutic lifestyle measures is difficult even if it reduces cardiovascular risk, improves quality of life and reduces medical care costs 35,36. Despite general knowledge about risk factors (smoking, high-fat diets, and lack of exercise) the English reject risk-reducing lifestyles based on logical personal and social reasons 37 . Poor urban residents in Fortaleza, in the State of Ceará, Brazil refuse to "forego the pleasures of life" to adopt a "healthier" lifestyle 38 . Innumerous cultural factors inhibit Kuwaitis from following diet and exercise recommendations 36. Similarly, in Bambuí, eliminating "fatty food" excludes the elderly from engaging fully in community life. Enjoying life's small pleasures - drinking a savory cup of medicinal tea, watching soccer with neighbors or eating a homemade cheese bun on Sunday - is enormously satisfying; it is one of the reasons for living! Although there is insufficient data to suggest that the emotional benefits of not adopting a healthier lifestyle outweigh the harmful effects of adopting, this is an intriguing question that deserves our attention.

Concepts of educational health among Bambui's health professionals are often imposed on patients in a top-down manner - like a military regime. In English, the word "regime" ("regime" in Portuguese) is defined as both "governmental rule or control" and "a system of therapy" 39. This dual meaning is also true in Portuguese - imposing an unjust set of laws, regulations and dictatorial government and an exercise and diet regime. Doctors' “regimes" are laws, rules and commands to be obeyed by elderly patients.

Ethnographic data suggests that, even in achieving the goal of screening for hypertension, patients' autonomy and free choice are often violated. The Brazilian philosopher Rosenfield 40 bases his thinking on that of English philosopher John Locke ${ }^{41}$. He argues, in his article Democracy and Liberty of Choice, that government intrusion into an individual's life threatens a pillar of democracy: the right to exercise free choice. When official organs ignore a citizen's desire by imposing standards of conduct and regulatory measures to control health behavior - what medicines to take, smoking, what to eat etc. - the essence of individuality is violated; "liberties are stolen" 40 . Free choice rightly belongs to the subjectivity and soul of every citizen. Anthropologist Bibeau 42 likewise criticizes public health experts - vested with moral authority - who define normative behavior "against all kinds of excess (food, fats, laziness, self-indulgence)" (p. 251); they usurp the layperson's decision about “what is good for people” (p. 250). Anthropology's relativistic discourse can combat this "normative homogeneity" and "popular estheticism" of our rich human condition, he defends 42 . Promoting personal autonomy, reminds Paulo Freire 43, is the touchstone of progressive education praxis.

In Bambuí, the authoritative imposition of doctors' "regimes" has led to attitudes of resistance 44 - splitting pills in half, abandoning treatment, spitting out medicine, secretly eating "fatty food" at night, smoking in the bathroom amongst elderly citizens. Powerless to confront medical authorities head-on, hypertensive elderly create "weapons of the weak" 44 or subtle ways 
of regaining "control" over their bodies and lives. Similar to other poor Brazilians 19, resistance is a strategy to confront, or even protest against, shortsighted hypertension control messages sent by health professionals oblivious to patients' lifestyles. However, narratives reveal that older people in Bambuí do assimilate the technical advances of blood pressure control to reduce the risks associated with hypertension - probably a reflection of family resilience 45 or, as Freire 43 says, the capacity of human beings to go beyond determining factors which shape their lives. Resisting blood pressure "control" may be a subtle way for the elderly to safeguard personal liberty, promote health and guarantee happiness during later life in Bambuí.

\section{Resumo}

Esta pesquisa etno-epidemiológica objetiva compreender a experiência humana da hipertensão enquanto percebida por pessoas idosas em Bambuí, Minas Gerais, Brasil. Mescla descrições etnográficas com dados numéricos. Significados acerca dos fatores correlacionados ao controle da pressão arterial são aprofundados. De 1,494 residentes $>60$ anos em uma base de coorte, 26 hipertensos idosos foram aleatoriamente selecionados e entrevistados utilizando signos, significados e ações. A análise multivariada associou ( $p<$ 0,001 ) o sexo feminino e renda mensal domiciliar ao tratamento da hipertensão mas não com controle da pressão adequado. Construções culturais conflitantes de "problema de pressão" contribuem para a "não-adesão" ao tratamento. Há uma tensão entre o "controle" da pressão arterial e os profissionais de saúde "controlando" a vida. "Regimes" prescritos pelos médicos proíbem os prazeres da vida, "controlando" a liberdade pessoal e o livre arbítrio. Dar voz aos idosos sobre suas condições sociais pode promover autonomia, bem estar e felicidade na últimas etapas da vida.

Hipertensão; Envelhecimento; Saúde do Idoso; Estudos de Coortes

\section{Contributors}

M. Nations participated in the data interpretation and writing up and revision of the text. J. O. A. Firmo collaborated in the collection and interpretation of the data and revision of the text. M. F. Lima-Costa carried out the epidemiological study, participated in the data interpretation and revision of the text. E. Uchôa designed the anthropological study, data interpretation and revision of the text.

\section{Acknowledgments}

To FINEP, CNPq and FAPEMIG for their financial support. We are grateful to our informants in Bambuí, Brazil for their courage and lust for life. Dr. M. Nations is grateful to $\mathrm{CNPq}$ for receiving the scientific productivity award during the writing of this paper. 


\section{References}

1. Medical Research Council trial of treatment of hypertension in older adults: principal results. MRC Working Party. BMJ 1992; 304:405-12.

2. Prencipe M, Casini AR, Santini M, Ferreti C, Scaldaferri N, Culasso F. Prevalence, awareness, treatment and control of hypertension in the elderly: results from a population survey. J Hum Hypertens 2000; 14:825-30.

3. Satish S, Markides KS, Zhang D, Goodwin JS. Factors influencing unawareness of hypertension among older Mexican-Americans. Prev Med 1996; 26:645-50.

4. Satish S, Stroup-Benham CA, Espini DV, Markides KS, Goodwin JS. Undertreatment of hypertension in older Mexican-Americans. J Am Geriatr Soc 1998; 46:405-10.

5. Fuentes R, Ilmaniemi N, Laurikainen E, Tuomilehto J, Nissinen A. Hypertension in developing economies: a review of population-based studies carried out from 1980 to 1998. J Hypertens 2000; 18:521-9.

6. World Health Organization. Populations aging: a public health challenge. Geneva: World Health Organization; 1998. (Fact Sheet, 135).

7. Lima-Costa MF, Matos DL. Tendências das condições de saúde e uso de serviços de saúde da população idosa brasileira: 20 anos de Sistema Único de Saúde. In: Departamento de Análise de Situação de Saúde, Secretaria de Vigilância em Saúde, Ministério da Saúde, organizador. Saúde Brasil 2008: 20 anos de Sistema Único de Saúde (SUS) no Brasil. Brasília:.Ministério da Saúde; 2009. p. 387-405. (Série G. Estatística e Informação em Saúde).

8. Firmo JOA, Lima-Costa, MF, Uchôa E. Projeto Bambuí: maneiras de pensar e agir de idosos hipertensos. Cad. Saúde Pública 2004; 20:1029-40.

9. Nations MK, Gomes AMA. Cuidado, "cavalo batizado" e crítica da conduta profissional pelo pacientecidadão hospitalizado no Nordeste brasileiro. Cad Saúde Pública 2007; 23:2103-12.

10. Ribeiro MMF, Amaral CFS. Medicina centrada no paciente e ensino médico: a importância do cuidado com a pessoa e o poder médico. Rev Bras Educ Méd 2008; 32:90-7.

11. Lima-Costa MF, Firmo JOA, Uchôa E. Cohort profile: the Bambuí (Brazil) Cohort Study of Aging. Int J Epidemiol 2010; [Epub ahead of print].

12. Firmo JOA, Barreto SM, Lima-Costa M.F. The Bambuí Health and Aging Study (BHAS): factors associated with the treatment of hypertension in older adults in the community. Cad Saúde Pública 2003; 19:817-27.

13. Corin E, Uchôa E, Bibeau G, Koumare B. Articulation et variations des systèmes de signes, de sens et d'actions. Psychopathologie Africaine 1992; 24:183-204.

14. Kleinman A. Writing at the margin: discourse between anthropology and medicine. Berkeley: University of California Press; 1995.

15. Kleinman A. What really matters: living a moral life amidst uncertainty and danger. Oxford: Oxford University Press; 2006.
16. Frankenberg R, Leeson J. Disease, illness and sickness: social aspects of the choice of healer in a Lusaka suburb. In: London JB, editor. Social anthropology and medicine. New York: Academic Press; 1976. p. 223-58.

17. Duarte LFD. Da vida nervosa nas classes trabalhadoras urbanas. Rio de Janeiro: Jorge Zahar Editor; 1986.

18. Leibing A, Groisman D. Tão alto quanto o morro: identidades localizadas de mulheres hipertensas na Favela da Mangueira. In: Ribeiro BT, Lima CC, Dantas MTL, organizadores. Narrativa, identidade e clínica. Rio de Janeiro: Edições IPUB/CUCA; 2001. p. 258-76.

19. Nations MK, Monte CMG. "I'm not dog, no!": cries of resistance against cholera control campaigns. Soc Sci Med 1996; 43:1007-24.

20. Rebhun LA. A heart too full: the weight of love in Northeast Brazil. J Am Folk 1994; 104:167-80.

21. Kleinman A. Patients and healers in the context of culture: an exploration of the borderland between anthropology and psychiatry. Berkeley/Los Angeles: University of California Press; 1980.

22. Nations MK. Epidemiological research of infectious diseases: quantitative rigor or rigormortis? Insights from ethnomedicine. In: Janes CR, Stall R, Gifford SM, editors. Anthropology and epidemiology. Boston Mass: D. Reidel Publishing Company; 1986. p. 97-124.

23. Bonomo E, Caiaffa WT, César CC, Lopes ACS, Lima-Costa MF. Consumo alimentar da população adulta segundo perfil sócio-econômico e demográfico: Projeto Bambuí. Cad Saúde Pública 2003; 19:1461-71.

24. Plasencia A, Ostfeld AM, Gruber SB. Effects of sex on differences in awareness, treatment and control of high blood pressure. Am J Prev Med 1988; 4:315-26.

25. Ribeiro D. O povo brasileiro: a formação e o sentido do Brasil. São Paulo: Companhia das Letras; 1995.

26. Loyola Filho AI, Lima-Costa MF, Uchôa E. Bambuí Project: a qualitative approach to self-medication. Cad Saúde Pública 2004; 20:1661-9.

27. Lima-Costa M F, Matos DL, Camarano AA. Evolução das desigualdades sociais entre idosos e adultos brasileiros: um estudo baseado na Pesquisa Nacional por Amostras de Domicílio (PNAD, 1998, 2003). Ciênc Saúde Coletiva 2006; 11:941-50.

28. Lima-Costa MF, Barreto SM, Firmo JOA, Uchôa E. Socioeconomic position and health in a population of Brazilian elderly: the Bambuí Health and Aging Study (BHAS). Rev Panam Salud Pública 2003; 13:387-94.

29. Carvalho F, Telarolli Jr. R, Machado JCMS. Uma investigação antropológica na terceira idade: concepções sobre a hipertensão arterial. Cad Saúde Pública 1998; 14:617-21.

30. Uchôa E, Firmo JOA, Lima-Costa MF. Envelhecimento e saúde: experiência e construção cultural. In: Minayo MCS, Coimbra Jr. CEA, organizadores. Antropologia, saúde e envelhecimento. Rio de Janeiro: Editora Fiocruz; 2001. p. 25-35. 
31. Snow LF. Popular medicine in a black neighborhood. In: Spicer EH, editor. Ethnic medicine in the southwest. Tuscon: University of Arizona Press; 1977. p. 19-95.

32. Blumhagen D. "Hyper-tension": a folk illness with a medical name. Cult Med Psychiatry 1980; 4: 197-224.

33. Kurisu S, Sato H, Kawagoe T, Ishihara M, Shimatani Y, Nishioka K, et al. Tako-tsubo-like left ventricular dysfunction with ST-segment elevation: a novel cardiac syndrome mimicking acute myocardial infarction. Am Heart J 2002; 143:448-55.

34. Good MD, Good BJ, Fischer MM. Introduction. Discourse and the study of emotion, illness and healing. Cult Med Psychiatry 1988; 12:1-7.

35. Appel LJ, Champagne CM, Harsha DW, Cooper LS, Obarzanek E, Elmer PJ, et al. Effects of comprehensive lifestyle modification on blood pressure control: main results of the PREMIER clinical trial. JAMA 2003; 289:2083-93.

36. Serour M, Alqhenaei H, Al-Saqabi S, Mustafa AR, Ben-Nakhi A. Cultural factors and patients' adherence to lifestyle measures. Br J Gen Pract 2007; 57:291-5.

37. Davison C, Frankel S, Smith GD. The limits of lifestyle: re-assessing "fatalism" in the popular culture of illness prevention. Soc Sci Med 1992; 34:675-85.
38. Lima MT, Bucher JSNF, Lima JWO. A hipertensão sob o olhar de uma população carente: estudo exploratório a partir dos conhecimentos, atitudes e práticas. Cad Saúde Pública 2004; 20:1079-87.

39. Morris W. The American heritage dictionary of the English language. $6^{\text {th }}$ Ed. New York: American Heritage Publishing Co.; 1970.

40. Rosenfield DL. Democracia e liberdade de escolha. Revista Opinião Filosófica 2010; 1:1-39.

41. Locke J. Two treatises of government. London: A. Millar; 1764.

42. Bibeau G. At work in the fields of public health: the abuse of rationality. Med Anthropol Q 1997; 11: 246-55.

43. Freire P. Pedagogia da autonomia: saberes necessários à prática educativa. São Paulo: Editora Paz \& Terra; 1966.

44. Scott JC. Domination and the arts of resistance: hidden transcripts. New Haven: Yale University Press; 1990.

45. Yunes MAM, Garcia NM, Albuquerque BM. Monoparentalidade, pobreza e resiliência: entre as crenças dos profissionais e as possibilidades da convivência familiar. Psicol Reflex Crit 2007; 20:444-53.

Submitted on 15/Sep/2010

Final version resubmitted on 29/Jun/2011 Approved on 13/Jul/2011 